\title{
Association of Diabetic Retinopathy and Maculopathy with Elevated HbA1c, Blood Pressure, Serum Creatinine, Microalbuminuria, Spot Urine Protein, Nephropathy and Diabetic Kidney Disease. An Experience from Data Analysis of 10,580 Diabetic Patients
}

\author{
Kamran Mahmood Ahmed Aziz* \\ Professor of Diabetes and Metabolism; Research Scientist and Clinical Investigator, Aseer Diabetes Center of Aseer Central Hospital, Ministry \\ of Health, Abha, Saudi Arabia.
}

Received: January 11, 2018; Accepted: February 02, 2018; Published: February 07, 2018

*Corresponding author: Aziz KMA, Diabetology Clinic, Aseer Diabetes Center, Aseer Central Hospital, Ministry of Health, P.O. Box 34, Abha, Saudi Arabia, Tel: 00966-568361040;E-mail:drkamran9999@yahoo.com

\section{Abstract}

Background: Diabetic kidney disease and retinopathy are the most important complications which usually co-exist together with high economic cost, morbidity, and mortality. Current research was designed to study these two complications and their associations with impaired glycemic control, elevated blood pressure, serum creatinine and proteinuria.

Methods: 10, 580 patients were selected for this study. Retinopathy was graded as: within normal limits (WNL), non-proliferative diabetic retinopathy (npdr mild, moderate or severe), or proliferative diabetic retinopathy (PDR) . For detection of diabetic kidney disease (DKD), patients were screened for elevated serum creatinine, microalbuminuria, and spot urine protein. Serum creatinine $\geq 1.5 \mathrm{mg} / \mathrm{dl}$ was labeled as "DKD".

Results: Severity (grading) of retinopathy increases with the advancement of duration of diabetes, HbA1c, serum creatinine, microalbuminuria, spot urine protein, and blood pressure (systolic and diastolic). ANOVA model P-values were significant for all tested variables ( $p<0.0001$ for all). Group of patients with maculopathy have higher levels of HbA1c, duration of diabetes, serum creatinine, microalbuminuria, spot urine protein and creatinine and their ratio (PCR), systolic and diastolic blood pressure with significant p-values. Significant, $\chi 2$ associations were observed for retinopathy with hypertension, and nephropathy with DKD (odds ratio 2.29 and 2.1, respectively; $\mathrm{p}<0.0001$ for all). For the development of retinopathy, ROC curve demonstrated cutoff point of $8.9 \%$ (g/dl) for HbA1c, with $67 \%$ sensitivity and 50\% specificity; 129 mmhg for systolic BP with $70 \%$ sensitivity and $55 \%$ specificity; and 79 mmhg for diastolic BP with $63 \%$ sensitivity and $51 \%$ specificity.

Conclusion: We concluded that all diabetic patients should be screened early for the detection of retinopathy, nephropathy, elevated serum creatinine, HbA1c and hypertension to prevent further diabetes complications.

\section{Introduction}

There is sufficient research evidence that diabetic retinopathy is associated with diabetic kidney disease (DKD) or chronic kidney disease (CKD) among diabetic subjects. There is also association of type- 2 diabetic proteinuria with retinopathy and the kidney function usually deteriorate with the presence of retinopathy. In other words, if both of these complications (retinopathy and nephropathy or DKD) coexists, the prognosis is poor and may lead to end stage renal disease (ESRD) [1-12].

Diabetic retinal disease and pathology is the commonest cause of visual impairment in patients with diabetes. Poor glycemic control, raised blood pressure (BP), duration of diabetes, and microalbuminuria or proteinuria are the main risk factors which initiates and then complicates this pathology $[13,14]$.

The likelihood of developing diabetic retinopathy is related to the duration of the disease. The rate of onset is variable, but after twenty years after the diagnosis of diabetes, $80 \%$ of type2 diabetics and nearly all type- 1 diabetics show some signs of retinopathy $[15,16]$.

The damaged retinal capillaries due to hyperglycemia are weak and possess out-pouchings of the vessel lumens (micro aneurysms), which eventually rupture to form hemorrhages within the retina, confined by the internal limiting membrane (ILM); they appear like dots and are called "dot-and-blot" hemorrhages. These fragile capillaries may leak fluid into the retina. When fluid is deposited under the macula (called "macular edema"), this interferes with the fine vision and common cause of vision loss with diabetic retinopathy (DR). Resolution/ reabsorption of this fluid leaves behind the sediment, composed lipid byproducts which appears waxy and yellow (called "hard exhudates"). As DR progresses, the blood vessels may also become 
obstructed causing oxygen supply compromise and resulting in infarction of the nerve fiber layer, which appears as fluffy, white patches (called "cotton wool spots, CWS") [17 ].

Although different classification or grading systems are available (such as Early Treatment Diabetic, ETDRS), conventionally, involvement of retina in diabetic state has been classified into three categories; background, preprolifrative retinopathy and proliferative retinopathy. Macula may be involved pathologically (called maculopathy/diabetic maculopathy) with any of these forms of retinopathy. Hence, retinopathy which affects the macula is separately described as diabetic maculopathy

For simplicity, retinopathy has also been classified as:

1- No visible retinopathy (within normal limits WNL) or normal fundus

2-Non proliferative diabetic retinopathy, NPDR (i.e., without neovascularization or abnormal blood vessel growth). This is further classified as early or mild non-proliferative retinopathy (micro-aneurysms only); moderate NPDR (characterized by multiple micro aneurysms, dot-and-blot hemorrhages, venous beading, and/or cotton wool spots); severe NPDR (hemorrhages/ micro aneurysms, cotton wool spots, venous beading, and severe intra retinal micro vascular abnormalities, IRMA). Within one year, $52-75 \%$ of patients falling into this category will progress to PDR [18].

3- Proliferative diabetic retinopathy, PDR (presence of neovascularization on the disc or elsewhere, NVE) and has a potential of serious visual consequences, such as vision loss, and poor prognosis. The retina has a high metabolic requirement; hence with continued ischemia, retinal cells respond by releasing angiogenic chemicals, factors and modulators such as vascular endothelial growth factor (VEGF), which stimulate growth of new retinal blood vessels to maintain the retinal blood supply and leading to the neovascularization. New vessels are leaky, fragile, and often misdirected and these may even grow off the retina and into the vitreous. As the vitreous shrinks with age, it pulls on these fragile vessels, casing rupture of new vessels resulting in a vitreous hemorrhage and sudden vision loss (called separately as "high risk PDR"). The new vessels are also the cause scar formation (with the time) and this result in strong anchors between the retina and vitreous causing tractional retinal detachment with extensive vitreous hemorrhage (defined separately as "advanced PDR") causing sudden vision loss. If not treated urgently (especially with maculopathy), permanent vision loss may result. Involvement of the macula with exudative or ischemic changes has a potential to involve the fovea, thus threatening vision. Exudative maculopathy may be amenable to treatment, but ischemic changes are not (diagnosed ideally by fluorescein angiography). [19-21].

In the past association of nephropathy (and its markers) and blood pressure with retinopathy have not been studied. Under this literature review and research background, our objective was to investigate association of diabetic retinopathy (and maculopathy) with impaired glycemic control, elevated blood pressure and with diabetic kidney disease markers (creatinine, microalbuminuria, and spot urine protein); and to study the association of diabetic retinopathy and diabetic kidney disease.

\section{Methods}

This is a prospective cross sectional analytical and cohort study, conducted at the diabetology clinic of Aseer Diabetes Center of Aseer Central Hospital, Ministry of Health Saudi Arabia. Study duration was more than 12 years, from August 2005 until September 2017. The study recruited 10,580 diabetic patients (after exclusion criteria) who, were followed up in this clinic. Study included both type-1 and type- 2 diabetic patients. Children (less than 13 years of age), patients with severe liver or hepatic disorders, patients demonstrating urinary tract infection, known cases of nephrotic syndrome or retinopathy before the onset of diabetes, patients with end stage renal disease (ESRD) or dialysis and pregnant women were excluded from the study.

Systolic and diastolic blood pressure (BP, in $\mathrm{mmHg}$ ) were measured by standardized methodology in resting position. Retinopathy was graded as: Within Normal Limits (WNL), Non-Proliferative Diabetic Retinopathy (NPDR either mild, moderate or severe), or Proliferative Diabetic Retinopathy (PDR), according to International Clinical Diabetic Retinopathy (DR) Disease Severity Scale [22]. Fundus or retina was examined by using computerized digital fundus photography camera (NIDEK Corporation, USA; approved by FDA for fundus photography). The data were reviewed by electronic file system and hospital information system (details given below).

\section{Laboratory Methods}

All samples were collected in fasting state of 12 hours, early in the morning. Both serum creatinine $(\mathrm{mg} / \mathrm{dl})$ and urine creatinine (mg/dl) were quantitatively measured by CREA methodology by Dimension ${ }^{\circledR}$ clinical chemistry system and device (Siemens Healthcare Diagnostics Inc. Newark, DE 19714, USA). The technique for the measurement of creatinine in plasma and urine involved picrate which, in the presence of a strong base $\mathrm{NaOH}$, chemically reacts with creatinine to form a red chromophore. The rate of increasing absorbance at $510 \mathrm{~nm}$ due to the formation of this chromophore is directly proportional to the creatinine concentration in the sample of blood or urine and which, is measured using by a bichromatic $(510,600 \mathrm{~nm})$ rate methodology. Hence, creatinine in the plasma was determined quantitatively [23-25].

Spot urine protein was measured by UCFP (Urinary/ Cerebrospinal Fluid Protein) method on Dimension ${ }^{\circledR}$ clinical chemistry system (Siemens healthcare diagnostics Inc. Newark, DE 19714, U.S.A). This is in vitro diagnostic test intended for the direct quantitative determination of total protein in human urine and cerebrospinal fluid, which is an adaptation of pyrogallol red molybdenum method by Y. Fujita, I. Mori and S. Kitano [26]. In the reaction sequence, pyrogallol red combined with sodium molybdate to form a red complex with maximum absorbance at $470 \mathrm{~nm}$. The protein in the sample reacted with this complex in acid solution to form a bluish-purple colored complex, which absorbs at $600 \mathrm{~nm}$. The absorbance at $600 \mathrm{~nm}$ was directly proportional to the concentration of protein in the sample. The 
analyte concentration was determined by calculation using a logit curve fit on a previously stored calibration curve. PCR (protein to creatinine ratio) was measured by spot urine protein / spot urine creatinine.

HbA1c was measured by A1c Flex® Reagent by the Dimension $\AA$ clinical chemistry system, in vitro diagnostic assay for the quantitative determination of both percent hemoglobin A1c and total hemoglobin, based on a turbid metric inhibition immunoassay (TINIA) principle, and the measurement of total hemoglobin is based on a modification of the alkaline hematin reaction, an NGSP certified methodology (Siemens healthcare diagnostics Inc. Newark, DE 19714, USA). The percentage of total hemoglobin that is glycated was calculated and reported as $\% \mathrm{HbA1c}$ (in $\mathrm{g} / \mathrm{dL}$ ), and final result has been standardized to the results obtained in DCCT.

For the detection of nephropathy and presence of albumin or protein in urine, fasting urine samples were examined for the presence of microalbuminuria, macro albuminuria or proteinuria. All urine samples were first examined for the presence of gross proteinuria by Quick Check $^{\mathrm{TM}}$ urinalysis reagent strips (ACON biotech, Co., Ltd.) to rule out macro albumin in urine. This technique is based on the phenomenon of $\mathrm{pH}$ indicators which releases hydrogen ions to the protein Samples which demonstrated macro albuminuria (in $\mathrm{mg} / \mathrm{dl}$ ) or gross proteinuria by the color indicator of the reagent strips (ranging from 1+ to 4+) were defined/labeled as "nephropathy". Samples with negative albumin were further examined for the presence of micro albumin in urine by MALB method used by Dimension $\AA$ clinical chemistry system and device, in vitro diagnostic test for quantitative measurement of albumin (mg/L) in human urine by particle-enhanced turbid metric inhibition immunoassay (PETINIA) methodology (Siemens Healthcare Diagnostics Inc. Newark, DE 19714, USA). Samples demonstrating microalbuminuria (albumin excretion in urine in the range of 30 $300 \mathrm{mg} / \mathrm{L}$ ) were also labeled and defined as nephropathy.

Patients demonstrating levels of serum creatinine $>1.5$ were defined as chronic renal/kidney disease (CRD/CKD) and these diabetic subjects were also considered "diabetic kidney disease" (DKD). Furthermore, patients demonstrating microalbuminuria or gross proteinuria were labeled as "nephropathy".

All laboratory sample requests were entered in a computer software and results retrieved by Natcom Hospital Information System (NATCOM HIS; National Computer System Co. Ltd [27].

\section{Statistical Methods}

Patients' data were analyzed by IBM ${ }^{\circledR}$ SPSS $\AA$ statistics, version 20, for Microsoft windows. All statistical tests were applied according to the available standard medical statistical methods. Data were summarized as percentages with mean \pm SD and $95 \% \mathrm{CI}$ for the variables.

ANOVA methodology was utilized to measure significant associations between the retinopathy groups and continuous variables, while assuring that all participants/data and their groups were independent. Post-hoc tests, least significant difference LSD and Bonferroni were also performed to assess the significant difference between the means of the groups of the graded retinopathy.

$\chi 2$ test (chi-square test for independence and association / Pearson's chi-square test ) was utilized for significant analysis of diabetic retinopathy with nephropathy and DKD associations. Logistic Regression, Odds Ratio and Protective Odds Ratio were used to measure associations of retinopathy with hypertension, nephropathy and DKD. Statistical power of $90 \%$ was built for detection of significance and p-values (two-sided) of less than 0.05 were considered significant. This study was reviewed and approved by the research committee of Aseer Diabetes Center, and all methodologies on subjects reported in current study were in accordance with the Helsinki Declaration of 1975 (revised in 2008).

\section{Results}

Demographic data for the patients are presented in Table-1. Hypertension was observed in $43 \%$ of patients and $37 \%$ demonstrated nephropathy; while 13\% demonstrated DKD/CKD.

Regarding retinopathy, the data are shown in table-2. Overall, $56 \%$ demonstrated normal fundus, while $44 \%$ demonstrated retinopathy during fundus examination. Retinopathy and fundus screening status is presented in table-2. Descriptive statistics for variables are shown in table- 3 .

Table- 4 demonstrates the ANOVA statistics between variables and different stages of retinopathy. It is evident form the table that severity of retinopathy (and its grading) increases with the advancement of duration of diabetes, HbA1c, serum creatinine, microalbuminuria, spot urine protein, and blood pressure (systolic and diastolic). It can be observed that p-values for ANOVA model are significant for all tested variables $(<0.0001$ for all; 0.002 for urine creatinine).

Patients with maculopathy were analyzed separately (regardless of stages of retinopathy). The data for the patients with maculopathy is shown in table-5. This table demonstrates levels of HbA1c, duration of diabetes, serum creatinine, microalbuminuria, spot urine protein and creatinine and their ratio (PCR), systolic and diastolic blood pressure. It is evident that there is a significant difference between the group of patients with or without maculopathy, with significant p-values.

\begin{tabular}{|l|l|l|}
\hline \multicolumn{2}{|l|}{ Table-1: Demographic data of diabetic patients } \\
\hline \multirow{2}{*}{ Parameters } & Description with N (\%) ; Totals = 10,580 \\
\hline \multirow{2}{*}{ Type of Diabetes } & Male & Female \\
\cline { 2 - 3 } & $6242(59 \%)$ & $4338(41 \%)$ \\
\hline \multirow{2}{*}{ Nephropathy } & Type-1 & Type-2 \\
\hline \multirow{2}{*}{ Hypertension (HTN) } & Positive & $8993(85 \%)$ \\
\cline { 2 - 3 } & $3914(37 \%)$ & Negative \\
\hline \multirow{2}{*}{$\begin{array}{l}\text { Diabetic Kidney } \\
\text { Disease } \\
\text { (DKD) status }\end{array}$} & $4549(43 \%)$ & $6666(63 \%)$ \\
\cline { 2 - 3 } & Positive & Negative \\
\hline & $1481(14 \%)$ & Negative \\
\hline
\end{tabular}


Association of Diabetic Retinopathy and Maculopathy with Elevated HbA1c, Blood Pressure, Serum Creatinine, Microalbuminuria, Spot Urine Protein, Nephropathy and Diabetic Kidney Disease. An Experience from Data Analysis of 10,580 Diabetic Patients

Table-2: Fundus photography / retinopathy screening status

Diabetic Retinopathy Status (N;\%)

\begin{tabular}{|c|c|}
\hline \multicolumn{2}{|c|}{ Diabetic Retinopathy Status (N;\%) } \\
\hline Normal (no diabetic retinopathy) & $56 \%$ \\
\hline Patients with diabetic retinopathy (total numbers) & $44 \%$ \\
\hline Mild NPDR & $24 \%$ \\
\hline Moderate NPDR & $11 \%$ \\
\hline Severe NPDR & $4 \%$ \\
\hline Proliferative DRP & $5 \%$ \\
\hline Overall patients with Maculopathy & $14 \%$ \\
\hline
\end{tabular}

Table-3: Descriptive statistics for the variables with mean \pm SD

\begin{tabular}{|c|c|}
\hline Variables & Mean \pm SD \\
\hline Age (years) & $53 \pm 13.5$ \\
\hline Diabetes duration (years) & $17 \pm 8.7$ \\
\hline Serum creatinine $(\mathrm{mg} / \mathrm{dl})$ & $0.967 \pm 0.593$ \\
\hline HbA1c $\%(\mathrm{~g} / \mathrm{dl})$ & $7.88 \pm 1.51$ \\
\hline Micro albumin in urine $(\mathrm{mg} / \mathrm{L})$ & $67 \pm 103$ \\
\hline Spot Urine protein & $52.8 \pm 28.9$ \\
\hline Urine creatinie $\mathrm{mg} / \mathrm{dl}$ & $119.6 \pm 71.87$ \\
\hline Protein to creatinine ratio $(\mathrm{PCR})$ & $.6025 \pm 2.06$ \\
\hline Systolic BP & $128.7 \pm 16.4$ \\
\hline Diastolic BP & $79.23 \pm 9$ \\
\hline
\end{tabular}

Table-4: ANOVA statistics between variables and the the graded retinopathy

\begin{tabular}{|c|c|c|c|c|c|c|c|}
\hline \multicolumn{8}{|c|}{ Type of DiabeticRetinopahty (grading) with mean \pm SD 95\% CI ; p-values } \\
\hline $\begin{array}{l}\text { Variables and } \\
\text { indicators }\end{array}$ & $\begin{array}{l}\text { Within Normal } \\
\text { Limits }\end{array}$ & Mild NPDR & $\begin{array}{l}\text { Moderate } \\
\text { NPDR }\end{array}$ & $\begin{array}{l}\text { Severe } \\
\text { NPDR }\end{array}$ & $\begin{array}{l}\text { Proliferative } \\
\text { diabetic } \\
\text { retinopathy } \\
\text { (PDR) }\end{array}$ & $\begin{array}{l}\text { ANOVA statistics ; } \\
\text { Post-hoc tests }\end{array}$ & $\begin{array}{c}\text { ANOVA } \\
\text { model } \\
\text { p-values }\end{array}$ \\
\hline $\mathrm{HbA1c} \%(\mathrm{~g} / \mathrm{dl})$ & $\begin{array}{c}7.62 \pm 1.517 .49 \text { to } \\
7.75\end{array}$ & $\begin{array}{l}8 \pm 1.317 .8 \\
\quad \text { to } 8.3\end{array}$ & $\begin{array}{l}8.1 \pm 1.47 \\
7.9 \text { to } 8.4\end{array}$ & $\begin{array}{c}8.22 \pm 1.29 \\
7.7 \text { to } 8.3\end{array}$ & $\begin{array}{l}8.36 \pm 1.38 \\
\quad \text { to } 8.7\end{array}$ & $\begin{array}{c}\text { F= 7.23; LSD and } \\
\text { Bonferroni p-values } \\
<0.05\end{array}$ & $<0.0001$ \\
\hline $\begin{array}{l}\text { Duration of } \\
\text { diabetes }\end{array}$ & $14.8 \pm 7.814 .3$ to 15.4 & $\begin{array}{c}22.5 \pm 8.4 \\
21.6 \text { to } 23.5\end{array}$ & $\begin{array}{c}25 \pm 7.24 \\
23.7 \text { to } 26.1\end{array}$ & $\begin{array}{c}27.2 \pm 7.25 \\
24.4 \text { to } 30\end{array}$ & $\begin{array}{c}28.77 \pm 7.7827 \\
\text { to } 30.4\end{array}$ & $\begin{array}{l}\mathrm{F}=\text { 128; LSD and } \\
\text { Bonferroni p-values } \\
<0.05\end{array}$ & $<0.0001$ \\
\hline $\begin{array}{l}\text { Serum creatinine } \\
(\mathrm{mg} / \mathrm{dl})\end{array}$ & $\begin{array}{c}0.87 \pm 0.4750 .836 \text { to } \\
0.903\end{array}$ & $\begin{array}{c}0.976 \pm 0.636 \\
0.904 \text { to } 1\end{array}$ & $\begin{array}{c}1.1 \pm 0.943 \\
0.956 \text { to } 1.26\end{array}$ & $\begin{array}{l}1.13 \pm 0.568 \\
0.908 \text { to } 1.35\end{array}$ & $\begin{array}{c}1.5 \pm 1.311 .2 \\
\text { to } 1.78\end{array}$ & $\begin{array}{c}\mathrm{F}=19 ; \mathrm{LSD} \text { and } \\
\text { Bonferroni p-values } \\
<0.05\end{array}$ & $<0.0001$ \\
\hline $\begin{array}{l}\text { Micro albu-min in } \\
\text { urine }(\mathrm{mg} / \mathrm{L})\end{array}$ & $35 \pm 1828.3$ to 39 & $\begin{array}{c}70 \pm 65.555 \\
\text { to } 84.9\end{array}$ & $\begin{array}{c}141 \pm 10192 \\
\text { to } 160\end{array}$ & $\begin{array}{l}180 \pm 115 \\
102 \text { to } 183\end{array}$ & $\begin{array}{c}193 \pm 131133 \\
\text { to } 198\end{array}$ & $\begin{array}{c}\text { F = 13.8; LSD and } \\
\text { Bonferroni p-values } \\
\quad<0.05\end{array}$ & $<0.0001$ \\
\hline $\begin{array}{l}\text { Spot Urine protein } \\
\qquad(\mathrm{mg} / \mathrm{dl})\end{array}$ & $31.9 \pm 28.722 .6$ to 41 & $\begin{array}{c}58.46 \pm 40.8 \\
36 \text { to } 90.5\end{array}$ & $\begin{array}{c}70 \pm 69.3 \\
55.6 \text { to } 120\end{array}$ & $\begin{array}{c}152 \pm 138 \\
130 \text { to } 239\end{array}$ & $\begin{array}{c}209 \pm 196189 \\
\text { to } 396\end{array}$ & $\begin{array}{c}\mathrm{F}=12.4 ; \mathrm{LSD} \text { and } \\
\text { Bonferroni } \quad \mathrm{p} \text {-values } \\
<0.05\end{array}$ & $<0.0001$ \\
\hline $\begin{array}{l}\text { Urine creatinie } \\
\qquad \mathrm{mg} / \mathrm{dl}\end{array}$ & $126 \pm 65120$ to 135 & $\begin{array}{c}112.3 \pm 55.5 \\
107 \text { to } 130\end{array}$ & $\begin{array}{c}108 \pm 54.53 \\
97 \text { to } 116\end{array}$ & $\begin{array}{c}103 \pm 48.8 \\
90 \text { to } 134\end{array}$ & $\begin{array}{l}88.78 \pm 39.7 \\
77.6 \text { to } 100\end{array}$ & $\begin{array}{c}\mathrm{F}=4.5 ; \mathrm{LSD} \text { and } \\
\text { Bonferroni p-values } \\
\quad<0.05\end{array}$ & 0.002 \\
\hline
\end{tabular}


Association of Diabetic Retinopathy and Maculopathy with Elevated HbA1c, Blood Pressure, Serum Creatinine, Microalbuminuria, Spot Urine Protein, Nephropathy and Diabetic Kidney Disease. An Experience from Data Analysis of 10,580 Diabetic Patients

Copyright: (C) 2018 Kamran MA Aziz

\begin{tabular}{|c|c|c|c|c|c|c|c|}
\hline PCR & $0.2 \pm 0.130 .12$ to 0.21 & $\begin{array}{l}0.61 \pm 1.58 \\
0.4 \text { to } 0.85\end{array}$ & $\begin{array}{c}1.07 \pm 2.7 \\
0.58 \text { to } 1.65\end{array}$ & $\begin{array}{l}1.79 \pm 3.22 \\
0.89 \text { to } 2.7\end{array}$ & $\begin{array}{c}2.6 \pm 70.99 \text { to } \\
5.7239\end{array}$ & $\begin{array}{c}\mathrm{F}=13.2 ; \mathrm{LSD} \text { and } \\
\text { Bonferroni } \quad \mathrm{p} \text {-values } \\
<0.05\end{array}$ & $<0.0001$ \\
\hline Systolic BP & $124 \pm 15123$ to 126 & $\begin{array}{c}132.5 \pm \\
15.6130 .5 \\
\text { to134.4 }\end{array}$ & $\begin{array}{c}135.5 \pm 15.6 \\
133 \text { to } 137\end{array}$ & $\begin{array}{c}136.5 \pm 12.4 \\
132 \text { to } 143\end{array}$ & $\begin{array}{c}141 \pm 19.5139 \\
\text { to } 148.5\end{array}$ & $\begin{array}{c}\mathrm{F}=\text { 33; LSD and } \\
\text { Bonferroni } \quad \text {-values } \\
<0.05\end{array}$ & $<0.0001$ \\
\hline
\end{tabular}

Table 5: T-test for the variables with and without maculopathy

\begin{tabular}{|c|c|c|c|c|c|}
\hline \multirow{2}{*}{ Variables } & \multicolumn{2}{|c|}{ Mean \pm SD ; $95 \%$ CI } & \multicolumn{3}{|c|}{ T-statistics } \\
\hline & With Maculopathy & Without Maculopathy & F-value & T-value & P-value \\
\hline HbA1c \% (g/dl) & $8.3 \pm 1.5 ; 8$ to 8.6 & $7.7 \pm 1.46 ; 7.6$ to 7.9 & 2.1 & 3.7 & 0.001 \\
\hline Duration of diabetes & $27.2 \pm 7.8 ; 26$ to 28.5 & $17.7 \pm 8.86 ; 17.2$ to 18.3 & 2.5 & 13.1 & $<0.0001$ \\
\hline Serum creatinine (mg/dl) & $1.3 \pm 1.17 ; 1.13$ to 1.5 & $0.91 \pm 0.56 ; 0.883$ to 0.947 & 75.4 & 7 & $<0.0001$ \\
\hline Micro albu-min in urine $(\mathrm{mg} / \mathrm{L})$ & $99.3 \pm 138 ; 69.9$ to 128.5 & $64.4 \pm 109 ; 56.3$ to 72.4 & 10.5 & 2.74 & 0.001 \\
\hline Spot Urine protein $(\mathrm{mg} / \mathrm{dl})$ & $82.7 \pm 143 ; 53.6$ to 112.7 & $50.4 \pm 119 ; 38.3$ to 62.5 & 5.6 & 2.1 & 0.02 \\
\hline Urine creatinie $\mathrm{mg} / \mathrm{dl}$ & $97.5 \pm 46.9 ; 87.9$ to 106.9 & $122.7 \pm 117.4$ to 128.4 & 6.6 & 3.1 & 0.001 \\
\hline PCR & $1.1 \pm 2.1 ; 0.68$ to 1.52 & $0.55 \pm 1.9 ; 0.398$ to 0.6 & 8.9 & 2.4 & 0.03 \\
\hline Systolic BP & $137 \pm 17 ; 135$ to 140 & $127 \pm 15 ; 126$ to 129 & 3.2 & 5.6 & $<0.0001$ \\
\hline Diastolic BP & $83.6 \pm 8.8 ; 80.5$ to 83.4 & $78 \pm 7.9 ; 77.4$ to 79.2 & 2.7 & 4.3 & $<0.0001$ \\
\hline
\end{tabular}

Table-6 demonstrates significant associations between retinopathy and HTN, nephropathy and DKD.

It can be observed from the table that $\chi 2$ value and odds ratio for retinopathy with HTN, nephropathy and DKD are 55.2 and 2.29 (95\% CI 1.84 to 2.86), 42.6 and 2.1 (95\% CI 1.7 to 2.63 ), 21.2 and 2.7 (95\% CI 1.74 to 4.1 ) respectively with significant p-values $(<0.0001$ for all $)$.

To explore the cutoff values for HbA1c and blood pressures, receiver operating curve (ROC) was used. Table-7 demonstrates the cut off value for $\mathrm{HbA1c}$ for the development of diabetic retinopathy; HbA1c $8.9 \%$ (g/dl) was found to be cutoff point for the development of retinopahty with $67 \%$ sensitivity and $50 \%$ specificity (AUC $=0.61 ; 95 \%$ CI 0.58 to $0.64 ; \mathrm{p}<0.0001$ ). Graphically, this is presented in figure-1.

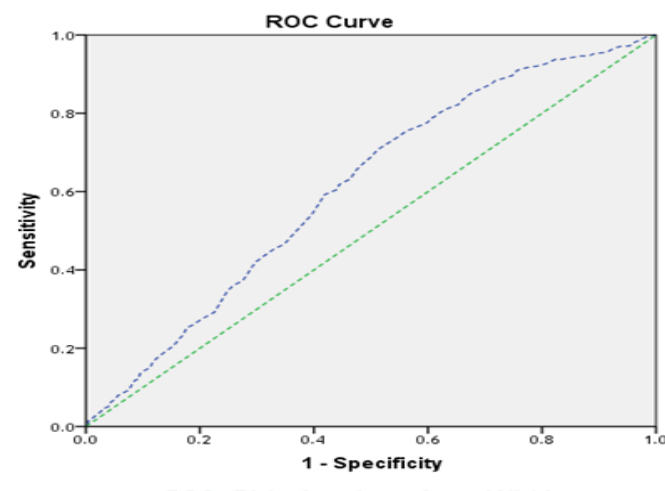

ROC : Diabetic retinopathy and HbA1c

Figure 1: ROC curve for retinopathy and $\mathrm{HbA1c}$
ROC curve values and statistics for diabetic retinopathy and cutoff values for systolic and diastolic BP are demonstrated in table-8. The cutoff point for the systolic BP and development of retinopathy was observed to be $129 \mathrm{mmHg}$ with $70 \%$ sensitivity and $55 \%$ specificity (AUC $=0.662 ; 95 \%$ CI 0.633 to 0.691 ; $\mathrm{p}<0.0001)$. The cutoff point for the diastolic BP and development of retinopathy was found to be $79 \mathrm{mmHg}$ with $63 \%$ sensitivity and $51 \%$ specificity (AUC $=0.585 ; 95 \%$ CI 0.555 to 0.616 ; $\mathrm{p}<$ $0.0001)$. This relationship is demonstrated graphically in figure 2 and 3 , respectively.

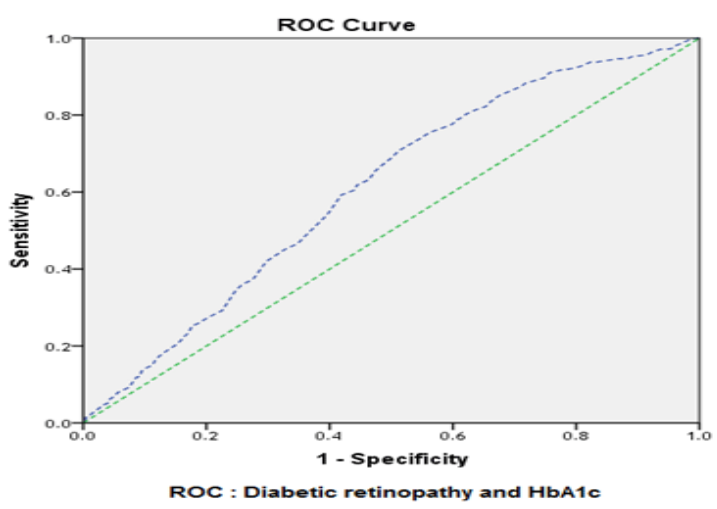

Figure 2: ROC curve for diabetic retinopathy and systolic BP 


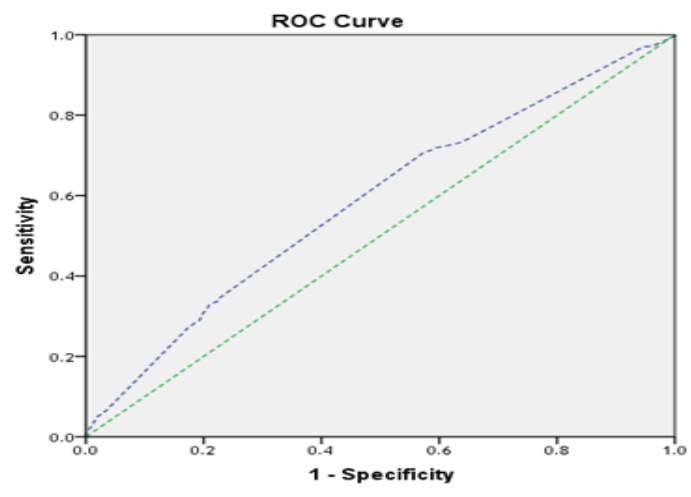

Figure 3: ROC curve for diabetic retinopathy and diastolic BP

\section{Discussion}

Present study was initiated to investigate the associations of elevated HbA1c and blood pressure with the development of retinopathy and Diabetic kidney disease; our aim was also to find cutoff values for HbA1c, systolic and diastolic blood pressures; our data has demonstrated significant associations with the conclusion that all diabetic patients should be screened early for the diabetes complications.

The complications of diabetes usually co-exist and progress together, if diabetes state is uncontrolled. Diabetic nephropathy (DN) and retinopathy also usually progress together. Type-2 diabetic subjects with proteinuria and retinopathy usually have a glomerulopahty or renal pathology. Furthermore, presence of retinopathy suggests that diabetic proteinuria or albuminuria

Table 6: Chi square test $\left(\chi^{2}\right)$ with logistic regression and odds ratio for retinopathy, nephropathy and DKD.

\begin{tabular}{|c|c|c|c|c|c|}
\hline \multirow[b]{2}{*}{$\begin{array}{c}\text { Variables tested } \\
\text { for } \chi^{2}\end{array}$} & \multicolumn{5}{|c|}{ Chi-square statistics with odds ratio and $95 \%$ CI } \\
\hline & $\chi^{2}$ Value & $\begin{array}{c}\text { Fisher's exact test } \\
\text { p-value }\end{array}$ & $\begin{array}{c}\text { Linear-by-linear } \\
\text { Association } \\
\text { p-value }\end{array}$ & $\chi^{2}$ p-value & $\begin{array}{c}\text { Logistic } \\
\text { Regression and Odds Ratio } \\
(95 \% \mathrm{CI})\end{array}$ \\
\hline $\begin{array}{c}\text { Retinopathy and } \\
\text { HTN }\end{array}$ & 55.2 & $<0.0001$ & $<0.0001$ & $<0.0001$ & $2.29 ; 95 \%$ CI 1.84 to 2.86 \\
\hline $\begin{array}{c}\text { Retinopathy and } \\
\text { nephropathy }\end{array}$ & 42.6 & $<0.0001$ & $<0.0001$ & $<0.0001$ & $2.1 ; 95 \%$ CI 1.7 to 2.63 \\
\hline $\begin{array}{c}\text { Retinopathy and } \\
\text { DKD/CKD }\end{array}$ & 21.2 & $<0.0001$ & $<0.0001$ & $<0.0001$ & $2.7 ; 95 \%$ CI 1.74 to 4.1 \\
\hline
\end{tabular}

Table-7: Results of ROC with AUC, 95\%CI, p-values and HbA1c cut off points

\begin{tabular}{|c|c|c|c|c|c|}
\hline Test variables & $\begin{array}{l}\text { Area under the } \\
\text { curve (AUC) }\end{array}$ & $\begin{array}{l}\text { Standard } \\
\text { error }\end{array}$ & 95\% CI & P-Value & $\begin{array}{l}\text { Coordinate HbA1c cutoff points for the } \\
\text { development of diabetic retinopathy }\end{array}$ \\
\hline $\begin{array}{l}\text { Diabetic retinopathy } \\
\text { and } \mathrm{HbA} 1 \mathrm{c}\end{array}$ & 0.61 & 0.015 & 0.580 to 0.640 & $<0.0001$ & $\begin{array}{c}8.9 \%(\mathrm{~g} / \mathrm{dl}) \\
\text { (67\% sensitivity and } 50 \% \text { specificity) }\end{array}$ \\
\hline
\end{tabular}

Table 8: Results of ROC with AUC, 95\% CI, p-values and triglyceride cutoff points

\begin{tabular}{|c|c|c|c|c|c|}
\hline Test variables & $\begin{array}{l}\text { Area under the curve } \\
\text { (AUC) }\end{array}$ & $\begin{array}{l}\text { Standard } \\
\text { error }\end{array}$ & $95 \% \mathrm{CI}$ & P-Value & $\begin{array}{c}\text { Coordinate blood pressure cutoff } \\
\text { points for the development of diabetic } \\
\text { retinopathy }\end{array}$ \\
\hline $\begin{array}{l}\text { Diabetic } \\
\text { retinopathy and } \\
\text { systolic BP }\end{array}$ & 0.662 & 0.015 & 0.633 to 0.691 & $<0.0001$ & $\begin{array}{l}129 \mathrm{mmHg} \\
\text { (70\% sensitivity and 55\% specificity) }\end{array}$ \\
\hline
\end{tabular}

is due to diabetic glomerulopahty or glomerulosclerosis (DKD). Association of diabetic glomerulosclerosis (or DKD) with retinopathy has been found in the research literature [28-36].

Retinopathy can be considered a risk marker and not a risk factor for the development of diabetic kidney disease since these micro vascular complications (diabetic nephropathy and diabetic retinopathy) share common determinants, such as poor glycemic, elevated blood pressure, and elevated lipids [37-39]. Diabetic retinopathy is one of the most common reasons for visual loss or blindness for the age group between 20 to 74 year-old adults $[40,41]$.

Microalbuminuria, a phenotype and marker of early diabetic nephropathy/DKD, is one of the risk factors of gross proteinuria or macro albuminuria in the progression of disease. Additionally, 
macro albuminuria itself is a risk factor for the development of decline in renal function and DKD [42-45].

Recently, it has been demonstrated that DR a risk factor for all-cause mortality, atherosclerosis, myocardial infarction or cardiovascular disease [22]. Co-existence of retinopathy with nephropathy usually indicates that nephropathy is due to diabetes and termed as diabetic kidney disease (DKD) or diabetic proteinuria. However, especially in type- 1 diabetics, the presence of proteinuria in association with short diabetes duration and/ or rapid decline of renal function, especially in the absence of diabetic retinopathy, warrants the need for renal biopsy [46-55].

Furthermore, research have demonstrated that both microalbuminuria and DR predict decline in renal function and development of CKD/DKD [56-62]. One of the common risk factor for the development of nephropathy and retinopathy is elevated blood pressure. Hypertension (HTN) usually aggravates nephropathy (or DKD) and retinopathy, and HTN must be controlled as it usually aggravates and complicates nephropathy and retinopathy [63-67].

While the effects of neovascularization in proliferative diabetic retinopathy (PDR) can be destructive with poor prognosis, the most common cause of vision loss among diabetic patients is macular edema or maculopathy. Macular edema may occur in NPDR, however it is more common in more severe cases of PDR due to leakage within neovascularization regions [68]. Furthermore, neovascularization can grow into the angle of the anterior chamber, causing obstruct outflow of aqueous fluid and ultimately resulting in acute glaucoma. Patient with DR usually do not have symptoms, which further delays the treatment. Hence, early retinopathy screening is essential to prevent complications of the diabetic eye disease or blindness [69-71].

Additionally, screening for nephropathy is as important as retinopathy screening. This can be achieved by routine urinalysis to detect presence of proteinuria. Early or incipient nephropathy can be detected by micro albumin in urine. Currently, spot urine protein and its ratio with urine creatinine, termed as protein to creatinine ration (PCR), is also recommended as this technique is easy and simple to perform. PCR ratio of up to $0.2 \mathrm{mg} / \mathrm{mg}$ is considered normal. Spot urine protein/creatinine relation can be interpreted as follows: normal ratio $<0.2 \mathrm{~g}$ protein per gram creatinine (which correlates with $0.2 \mathrm{~g}$ protein/day); nephrotic range ratio $>3.5$ (which correlates with 3.5 g protein). $300 \mathrm{mg} /$ day or higher is obviously abnormal and this higher value correlates to an approximate PCR of $0.2 \mathrm{mg} / \mathrm{mg}(200 \mathrm{mg} / \mathrm{g}$ ) [72-81].

Several conditions, including marked hyperglycemia and hypertension, may cause transient elevations of urinary albumin or proteinuria. Hence, control of blood pressure and hyperglycemia is essential to prevent development and progression of nephropathy [82-85]

Current study was designed to investigate the associations of retinopathy with the development of diabetic kidney disease under the influence of high $\mathrm{HbA1c}$, blood pressure and proteinuria, which, to our best knowledge, has not been investigated in the past medical history.
Our data analysis has demonstrated that $43 \%$ were diagnosed with HTN, 37\% with nephropathy, 14\% with DKD while 44\% demonstrated diabetic retinopathy. We analyzed the data for maculopathy separately and its associations with other variables. Overall, $14 \%$ of patients demonstrated maculopathy .

Table-3 demonstrates levels or grading of diabetic retinopathy with levels of $\mathrm{HbA1c}$, duration of diabetes, serum creatinine, micro albumin in urine, spot urine protein, spot urine creatinine, PCR, systolic and diastolic blood pressures. It is evident from the table that all variable values increase with increasing levels of retinopathy. ANOVA model demonstrates significant p-values (< 0.0001 for all variables).

We analyzed data for maculopathy separately as it can be present at any stage of retinopathy. It is evident from table- 4 that patients with maculopathy have long duration of diabetes, higher levels of Hba1c, serum creatinine, microalbuminuria, spot urine protein and creatinine with PCR, and elevated systolic and diastolic blood pressures with significant p-values. All this data signifies the importance of good glycemic control, and blood pressure control to prevent development and progression of nephropathy and retinopathy. Best possible efforts should be done to control elevated blood glucose levels by oral agents or insulin. Under these circumstances, control of hyperlipidemia will be essential also to prevent further complications diabetes. Additionally, patients with diabetic foot or low ankle brachial index (ABI), with nephropathy and/or retinopathy should be given special attention as these subjects have poor prognosis. Furthermore, patients with hypothyroidism should be screened also for elevated blood pressure, elevated lipids and presence of proteinuria as this endocrine condition predisposes for the diabetes complications [86-96]

Regarding patients with diabetes and advanced renal disease or DKD, physicians must also screen for the presence of anemia. It should be noted that, anemia may occur even before the onset of advanced kidney failure or DKD (serum creatinine $<1.8 \mathrm{mg}$ / dl); this is due to erythropoietin deficiency. Furthermore, anemia is considered a risk factor for the progression of kidney disease and retinopathy. Such patients must be referred to nephrology specialist care units and it is recommended starting erythropoietin treatment when hemoglobin levels are less than $11 \mathrm{~g} / \mathrm{dl}$, with the targets of $12-13 \mathrm{~g} / \mathrm{dl}$. HTN should be monitored with erythropoietin therapy as this may increase blood pressure [97,98]. Hence, management of DKD or CKD may be challenging and needs diabetologist and nephrologist, and other specialties consultation for proper workup. All efforts should be done to screen diabetic patients for HTN, dyslipidemia, nephropathy and retinopathy; multidisciplinary approach is also required at tertiary care diabetes centers. Further research at multicenter level is required to confirm findings and reports of the current study.

\section{Conclusion}

In tertiary care diabetes centers, early screening for nephropathy, retinopathy and dyslipidemia is recommended; to avoid diabetes related renal and ophthalmic complications. Blood glucose and blood pressure control should be on the targets as 
these conditions aggravate diabetes related complications. Best available guidelines and medications should be used according to the evidence based medicine and recent clinical trials $[87,99-$ $106]$

\section{References}

1. Trevisan R, Vedovata M, Mazzon C, Coracin A, Lori E, Tiengo A, et al Concomitance of Diabetic Retinopathy and Proteinuria Accelerates the Rate of Decline of Kidney Function in Type-2 Diabetic Patients. Diabetes Care. 2002; 25(11):2026-2031.

2. Schwartz MM, Lewis EJ, Leonard-Martin T, Lewis JB, Battle D, The Collaborative Study Group: Renal pathology patterns in type 2 diabetes mellitus: relationship with retinopathy. Nephrol Dial Transplant. 1998;13(10):2547-2552.

3. Gall MA, Rossing P, Skott P, Damsbo P, Vaag A, Bech K, et al Prevalence of micro- and macroalbuminuria, arterial hypertension, retinopathyand large vessel disease in European Type-2 (noninsulin-dependent) diabetic patients. Diabetologia 1991;34:655661.

4. Lippert J, Ritz E, Schwarzbeck A, Scheider P. The rising tide of end stage renal failure from diabetic nephropathy type II: an epidemiologica lanalysis. Nephrol Dial Transplant. 1995;10(4):462467.

5. Ritz E. Nephropathy in type 2 diabetes. J Int Med. 1999;245(2):111126.

6. Parving HH, Gall MA, Skott P, Jorgensen HE, Lokkegaard H, Jorgensen $F$, et al. Prevalence and causes of albuminuria in non-insulindependent diabetic patients. Kidney Int. 1992;41(4):758-762.

7. Christensen PK, Larsen S, Horn T, Olsen S, Parving HH. Causes of albuminuria in patients without diabetic retinopathy. Kidney Int 2000;58:1719-1731. Doi: 10.1046/j.1523-1755.2000.00333.x

8. Fioretto P, Mauer M, Brocco E, Velussi M, Muollo M, Sambataro M, et al. Patterns of renal injury in NIDDM patients with microalbuminuria. Diabetologia. 1996;39(12):1569-1576.

9. Grunwald JE, Alexander J, Ying GS, Maquire M, Daniel E, Parker $\mathrm{C}$, et al. Retinopathy and chronic kidney disease in the Chronic Renal Insufficiency Cohort (CRIC) study. Arch Ophthalmol. 2012;130(9):1136-1144. Doi: 10.1001/archophthalmol.2012.1800

10. Grunwald JE, Alexander J, Maguire M, Revell W, James Pl, Ojo A,et al. Prevalence of ocular fundus pathology in patients with chronic kidney disease. Clin J Am Soc Nephrol 2010;5(5):867-873.

11. Kamran MA Aziz. Association between High Risk Foot, Retinopathy and HbA1c in Saudi Diabetic Population. Pak J Physiology. 2010;6(2):22-28

12. Kamran MA Aziz. Association of Microalbuminuria with Ischemic Heart Disease, Dyslipidemia and Obesity among Diabetic Patients: Experience from 5 Year Follow up Study of 1415 Patients. Bioenergetics 2014;3:118 Doi:10.4172/2167-7662.1000118

13. The Diabetes Control and Complications Trial Research Group. The effect of intensive treatment of diabetes on the development and progression of long-term complications in insulin-dependent diabetes mellitus. N Engl J Med. 1993; 329:977-986.

14. Tight blood pressure control and risk of macro vascular and micro vascular complications in type 2 diabetes: UKPDS 38. UK Prospective Diabetes Study Group. BMJ. 1998;317:703. PubMed PMID: 9732337. Doi: $10.1136 / \mathrm{bmj} .317 .7160 .703$

15. Klein R, Klein BE, Moss SE, Davis MD, DeMets DL. The Wisconsin Epidemiologic Study of Diabetic Retinopathy: III. Prevalence and risk of diabetic retinopathy when age at diagnosis is 30 or more years. Arch Ophthalmol 1984; 102(4):527-532.

16. Klein R, Klein BE, Moss SE, Davis MD, DeMets DL. The Wisconsin Epidemiologic Study of Diabetic Retinopathy: II. Prevalence and risk of diabetic retinopathy when age at diagnosis is less than 30 years. Arch Ophthalmol 1984b; 102(4):520-526.

17. Frank RN. Diabetic retinopathy. N Engl J Med. 2004;350(1):48-58.

18. Aiello LM. Perspectives on diabetic retinopathy. Am J Ophthalmol 2003;136(1):122-135.

19. Fong DS, Aiello L, Gardner TW, King GL, Blankenship G, Cavallerano JD, et al. Diabetic retinopathy. Diabetes Care. 2003;26(1):226-229.

20. Wilkinson CP, Ferris FL, Klein RE, Lee PP, Davis M, Dills D, et al. Proposed international clinical diabetic retinopathy and diabetic macular edema disease severity scales. Ophthalmology. 2003;110(9):1677-1682. Doi: 10.1016/S0161-6420(03)00475-5

21. Wilkinson CP, Ferris FL, Klein RE, Lee PP, Agardh CD, Davis M, Dills D, Kampik A, Pararajasegaram R, Verdaguer JT. Proposed international clinical diabetic retinopathy and diabetic macular edema disease severity scales. Ophthalmology. 2003;110(9):1677-1682.

22. Meredith TA. The diabetic vitrectomy study. In: Kertes C, ed. Clinical Trials in Ophthalmology-A Summary and Practice Guide. 1998:3748.

23. Klein R, Klein BEK, Moss SE, Matthew D, David L. The Wisconsin Epidemiological Study of Diabetic Retinopathy. X. Four-year incidence and progression of diabetic retinopathy when age of diagnosis is 30 years or more. Arch Ophthalmol. 1989;107(2):244249. Doi: 10.1001/archopht.1989.01070010250031

24. Mitchell RJ. Improved method for specific determination of creatinine in serum and urine. Clin Chem. 1973;19:408-410.

25. Slot C. Plasma creatinine determination. A new and specific Jaffe reaction method. Scand J Clin Lab Invest 1965;17(4): 381-387.

26. Bishop Michael L. Clinical Chemistry: Principles and Correlations 2nd ed. Philadelphia: Lippincott JB, Company. 1992; 441.

27. Fujita Y, Mori I, Kitano S. Color reaction between pyrogallol red molybdenum (VI) complex and protein. Bunseki Kagaku. 1983;32:E379-E386.

28. NATCOM Hospital Information System (NATCOM HIS). National Computer System Co, Ltd.

29. Deckert T, Feldt-Rasmussen B, Borch-Johnsen K, Jensen T, KofoedEnevoldsen A. Albuminuria reflects widespread vascular damage. The Steno hypothesis. Diabetologia. 1989;32(4):219-226.

30. US Renal Data System: USRDS 2003 Annual Data Report: Atlas of End-Stage Renal Disease in the United States. Bethesda, MD, National 
Institute of Health, National Institute of Diabetes and Digestive and Kidney Diseases. 2003

31. Osterby R, Gall MA, Schmitz A, Nielsen FS, Nyberg G, Parving HH. Glomerular structure and function in proteinuric Type 2 (non-insulindependent) diabetic patients. Diabetologia. 1993;36(10):10641070.

32. Parving $\mathrm{H}-\mathrm{H}$, Gall $\mathrm{M}-\mathrm{A}$, Sk㭵t $\mathrm{P}$, J㭵gensen HE, L国kkegaard $\mathrm{H}$, J 0 rgensen F, et al. Prevalence and causes of albuminuria in noninsulin-dependent diabetic patients. Kidney Int. 1992;41:758-762.

33. United Kingdom Prospective Diabetes Study Group. Overview of 6 years' therapy of type II diabetes: A progressive disease. Diabetes. 1995;44(11):1249-1258.

34. United Kingdom Prospective Diabetes Study Group. Intensive blood glucose control with sulphonylureas or insulin compared with conventional treatment and risk of complications in patients with type 2 diabetes (UKPDS 33). Lancet. 1998;352(9131):837-853.

35. Costa LA, Canani LH, Lisboa HR, Tres GS, Gross JL. Aggregation of features of the metabolic syndrome is associated with increased prevalence of chronic complications in type 2 diabetes. Diabet Med. 2004;21(3):252-255.

36. Pedro RA, Ramon SA, Marc BB, Juan FB, Isabel MM. Prevalence and relationship between diabetic retinopathy and nephropathy, and its risk factors in the North- East of Spain, a populationbased study. Ophthalmic Epidemiol. 2010;17(4):251-265. Doi: 10.3109/09286586.2010.498661

37. The Diabetes Control and Complications Trial/ Epidemiology of Diabetes Interventions and Complications Research Group. Retinopathy and nephropathy in patients with type 1 diabetes four years after a trial of intensive therapy. N Engl J Med. 2000;342:381389. Doi: $10.1056 /$ NEJM200002103420603

38. DCCT Research Group: The relationship of glycemic exposure (HbA1c) to the risk of development and progression of retinopathy in the Diabetes Control and Complications Trial. Diabetes. 1995;44(8):968-983. Doi: 10.2337/diab.44.8.968

39. The Diabetes Control and Complications Trial/Epidemiology of Diabetes Interventions and Complications Research Group. Retinopathy and nephropathy in patients with type- 1 diabetes four years after a trial of intensive therapyN Engl J Med. 2000;342:381389. Doi: 10.1056/NEJM200002103420603

40. Gross JL, Stein ACR, Beck MO, Fucks SC, Silveiro SP, Azevedo MJ, et. al : Risk factors for development of proteinuria in type II (noninsullin dependent) diabetic patients. Brazilian J Med Biol Res. 1993;26(12):1269-1278.

41. Powers AC, Longo DL, Kasper DL, et al. Harrison's Principles of Internal Medicine. 18th ed. New york; The McGraw Hill companies: 2012.

42. Valmadrid CT, Klein R, Moss SE, Klein BE: The risk of cardiovascular disease mortality associated with microalbuminuria and gross proteinuria in persons with older-onset diabetes mellitus. Arch Intern Med. 200;160(8):1093-1100.
43. Mogensen CE. Microalbuminuria as a predictor of clinical diabetic nephropathy. Kidney Int. 1987;31(2):673-689. Doi: 10.1038/ ki.1987.50

44. Mogensen CE, Christensen CK. Predicting diabetic nephropathy in insulin dependent patients. N Engl J Med. 1984; 311(2):89-93. Doi: 10.1056/NEJM198407123110204

45. Mogensen CE, Chachati A, Christensen CK, Close CF, Deckert T, et al. Microalbuminuria: an early marker of renal involvement in diabetes. Uremia Invest 1985;9(2):85-95

46. Dinneen SF, Gerstein HC. The association of microalbuminuria and mortality in non-insulin-dependent diabetes mellitus. A systematic overview of the literature. Arch Intern Med. 1997;157(13):14131418.

47. Kramer CK, Rodrigues TC, Canani LH, Gross JL, Azevedo MJ. Diabetic retinopathy predicts all-cause mortality and cardiovascular events in both type 1 and 2 diabetes: meta-analysis of observational studies. Diabetes Care 2011;34(5):1238-1244. Doi: 10.2337/dc11-0079

48. Kramer HJ, Nguyen QD, Curhan G, Hsu CY: Renal insufficiency in the absence of albuminuria and retinopathy among adults with type 2 diabetes mellitus. JAMA. 2003;289(24):3273-3277. Doi: 10.1001/ jama.289.24.3273

49. Mauer M, Fioretto P, Woredekal Y, Friedman EA: Diabetic nephropathy. In Diseases of the Kidney and Urinary Tract. 7th ed. Schrier RW, Ed. Lippincott Williams \& Wilkins;:2001.

50. Kawasaki R, Cheung N, Islam FM, et al.; Multi-Ethnic Study of Atherosclerosis. Is diabetic retinopathy related to subclinical cardiovascular disease? Ophthalmology. 2011;118(5):860-865. Doi: 10.1016/j.ophtha.2010.08.040

51. Son JW, Jang EH, Kim MK, Kim IT, Roh YJ, Baek KH, et al. Diabetic retinopathy is associated with subclinical atherosclerosis in newly diagnosed type 2 diabetes mellitus. Diabetes Res Clin Pract. 2011;91(2):253-259. Doi: 10.1016/j.diabres.2010.11.005

52. Cheung N, Wang JJ, Klein R, Couper DJ, Sharrett AR, Wong TY, et al. Diabetic retinopathy and the risk of coronary heart disease: the Atherosclerosis Risk in Communities Study. Diabetes Care. 2007;30(7):1742-1746.

53. Kawasaki R, Tanaka S, Tanaka S, et al. Risk of cardiovascular diseases is increased even with mild diabetic retinopathy: the Japan diabetes complications study. Ophthalmology. 2013;120(3):574-582. Doi: 10.1016/j.ophtha.2012.08.029

54. Juutilainen $\mathrm{A}$, Lehto $\mathrm{S}$, Ronnemaa $\mathrm{T}$, et al. Retinopathy predicts cardiovascular mortality in type 2 diabetic men and women. Diabetes Care. 2007;30(2):292-299.

55. Gerstein HC, Ambrosius WT, Danis R, et al. Diabetic retinopathy, its progression, and incident cardiovascular events in the ACCORD trial. Diabetes Care. 2013;36(5):1266-1271. Doi: 10.2337/dc12-1311

56. Edwards MS, Wilson DB, Craven TE, et al. Associations between retinal micro vascular abnormalities and declining renal function in the elderly population: the Cardiovascular Health Study. Am J Kidney Dis 2005;46(2):214-224. 
57. Tong PC, Kong AP, So WY, et al. Interactive effect of retinopathy and microalbuminuria on all-cause mortality, cardiovascular and renal end points in Chinese patients with Type 2 diabetes mellitus. Diabet Med. 2007;24(7):741-746

58. Suzuki Y, Ueno M, Hayashi H, et al. Morphologic study of the kidney in Japanese non-insulin dependent patients. J Diabet Complications. 1991;5(2-3):79-81

59. Klein R, Knudtson MD, Klein BE, Zinman B, Gardiner R, Suissa S, et al. The relationship of retinal vessel diameter to changes in diabetic nephropathy structural variables in patients with type 1 diabetes. Diabetologia. 2010;53(8):1638- 1646. Doi: 10.1007/s00125-0101763-3

60. Moriya T, Tanaka K, Hosaka T, Hirasawa Y, Fujita Y. Renal structure as an indicator for development of albuminuria in normo- and microalbuminuric type 2 diabetic patients. Diabetes Res Clin Pract 2008;82(3):298-304. Doi: 10.1016/j.diabres.2008.08.015

61. Savage S, Estacio RO, Jeffers B, Schrier RW. Urinary albumin excretion as a predictor of diabetic retinopathy, neuropathy, and cardiovascular disease in NIDDM. Diabetes Care. 1996;19(11):1243-1248

62. Wirta O, Pasternack A, Mustonen J, Laippala P, Lahde Y. Retinopathy is independently related to microalbuminuria in type 2 diabetes mellitus. Clin Nephrol. 1999;51(6):329-334.

63. Cruickshanks KJ, Ritter LL, Klein R, Moss SE. The association of microalbuminuria with diabetic retinopathy. The Wisconsin Epidemiologic Study of Diabetic Retinopathy. Ophthalmology. 1993;100(6):862-867.

64. Adler AI, Stratton IM, Neil HA, Yudkin JS, Matthews DR, Cull CA, et al. Association of systolic blood pressure with macrovascular and microvascular complications of type 2 diabetes (UKPDS 36): prospective observational study. BMJ. 2000;321:412-419. Doi: $10.1136 / \mathrm{bmj} .321 .7258 .412$

65. Cignarelli M, De Cicco ML, Damato A, Paternostro A, Pagliarini S, Santoro S, et al. High systolic blood pressure increases prevalence and severity of retinopathy in NIDDM patients. Diabetes Care. 1992;15:1002-1008.

66. Brenner BM, Cooper ME, de Zeeuw D, Grunfeld JP, Keane WF, Kurokawa K, et al. The Losartan renal protection study-rationale, study design and baseline characteristics of RENAAL (Reduction of Endpoints in NIDDM with the Angiotensin II Antagonist Losartan). J Renin Angiotensin Aldosterone System. 2000;1(4):328-335.

67. Gall MA, Hougaard P, Borch-Johnsen K, Parving HH. Risk factors for development of incipient and overt diabetic nephropathy in patients with non-insulin dependent diabetes mellitus: prospective, observational study. BMJ. 1997; 314:783-788. Doi: 10.1136/ bmj.314.7083.783

68. Parving HH, Hommel E, Mathiesen E, Skott P, Edsberg B, Bahnsen $\mathrm{M}$, et al. Prevalence of microalbuminuria, arterial hypertension, retinopathy and neuropathy in patients with insulin dependent diabetes. Br Med J (Clin Res Ed). 1988; 296(6616):156-160.

69. Wani JS, Nasti AR, Ashai M, Keng M, Qureshi T, Rashid S. Incidence of maculopathy in non-proliferative and proliferative diabetic retinopathy. JK-Practitioner. 2003; 10(4):275-278.

70. Nguyen TT, Wong TY. Retinal vascular changes and diabetic retinopathy. Curr Diab Rep. 2009;9(4):277-283.

71. Early Treatment Diabetic Retinopathy Study Research Group. Treatment techniques and clinical guidelines for photocoagulation of diabetic macular edema. Early Treatment Diabetic Retinopathy Study report number 2. Ophthalmology 1987;94(7):761-774.

72. American Academy of Ophthalmology. 2016.

73. Rodby R, Rohde R, Sharon Z, Pohl M, Bain R, Lewis E. The urine protein to creatinine ratio as a predictor of 24-hour urine protein excretion in type 1 diabetic patients with nephropathy. The Collaborative Study Group. Am J Kidney Dis 1995;26(6):904-909.

74. Eddy A, McCulloch L, Liu E, Adams J. A relationship between proteinuria and acute tubulo-interstitial disease in rats with experimental nephrotic syndrome. Am J Pathol. 1991;138(5):11111123.

75. Côté A, Brown M, Lam E, von Dadelszen P, Firoz T, Liston R, et al. Diagnostic accuracy of urinary spot protein:creatinine ratio for proteinuria in hypertensive pregnant women: Systematic review. BMJ. 2008;336(7651):1003-1006.

76. Lemann J, Doumas B. Proteinuria in health and disease assessed by measuring the urinary protein/creatinine ratio. Clin Chem. 1987;33(2 Pt 1):297-299.

77. Ginsberg J, Chang B, Matarese R, Garella S. Use of single voided urine samples to estimate quantitative proteinuria. N Engl J Med. 1983;309(25):1543-1546. Doi: 10.1056/NEJM198312223092503

78. Ruggenenti P, Gaspari F, Perna A, Remuzzi G. Cross sectional longitudinal study of spot morning urine protein:creatinine ratio, 24 hour urine protein excretion rate, glomerular filtration rate, and end stage renal failure in chronic renal disease in patients without diabetes. BMJ. 1998;316(7130):504-509.

79. Abitbol C, Zilleruelo G, Freundlich M, Strauss J. Quantitation of proteinuria with urinary protein/creatinine ratios and random testing with dipsticks in nephrotic children. J Pediatr 1990;116(2):243-247.

80. Morgenstern B, Butani L, Wollan P, Wilson D, Larson T. Validity of protein-osmolality versus protein-creatinine ratios in the estimation of quantitative proteinuria from random samples of urine in children. Am J Kidney Dis. 2003;41(4): 760-766.

81. Houser M. Assessment of proteinuria using random urine samples. J Pediatr. 1984;104(6): 845-848.

82. Kamran MA Aziz. Correlation of Urine Biomarkers: Microalbuminuria and Spot Urine Protein among Diabetic Patients. Application of Spot Urine Protein in Diabetic Kidney Disease, Nephropathy, Proteinuria Estimation, Diagnosing and Monitoring. Recent Pat Endocr Metab Immune Drug Discov. 2015;9(2):121-133.

83. Molitch ME, DeFronzo RA, Franz MJ, Keane WF, Mogensen CE, Parving HH,et al.; American Diabetes Association. Nephropathy in diabetes. Diabetes Care. 2004;27(suppl 1): S79-S83. 
84. Duckworth W, Abraira C, Moritz T, et al.; VADT Investigators. Glucose control and vascular complications in veterans with type 2 diabetes [published correction appears in N Engl J Med. N Engl J Med. 2009;360(2):129-139.

85. Brenner Bm, cooper ME, De Zeeuw DD, Keane WF, Mitch WE, Parving $\mathrm{HH}$, et. al. for The RENAAL Study Investigators: Effects of losartan on renal and cardiovascular outcomes in patients with type 2 diabetes and nephropathy. N Engl J Med. 2001;345:861-869. DOI: 10.1056/ NEJMoa011161

86. Levey AS, Coresh J, Balk E, Kausz AT, Levin A, Steffes MW, Hogg RJ, Perrone RD, Lau J, Eknoyan G: National Kidney Foundation practice guidelines for chronic kidney disease: evaluation, classification, and stratification. Ann Intern Med. 2003;139(2):137-147.

87. Kamran MA Aziz. Management of Type- 1 and Type- 2 Diabetes by Insulin Injections in Diabetology Clinics - A Scientific Research Review. Recent Pat Endocr Metab Immune Drug Discov. 2012;6(2):148-170. Doi: 10.2174/187221412800604608

88. Standards of Medical Care in Diabetes, Diabetes Care. 2018;40(1): S1-S159.

89. Aziz KMA . Application of Premixed Insulin NovoMix®30 and Novo Rapid® as Multiple Daily Injections or as Basal Bolus Format in Selected Diabetic Patients: Technical Evidence from Prospective Case Series. Int J Diabetol Vasc Dis Res 2017;5(2e):1-2. Doi: 10.19070/2328-353X-1700013e

90. Kamran MA Aziz . Effect of Serum Uric Acid in Augmentation of Insulin Secretion and Improvement of HbA1c in Diabetic Patients: Proposed Statistical Regression Models for Uric Acid, HbA1c and Insulin. Journal of Research in Diabetes, 2014. Doi:10.5171/2014.237887

91. Aziz KMA. Using Premixed Biphasic Insulin Analogs Humalog® Mix 25 and Humalog $\circledR^{\text {Mix }} 50$ in Basal Bolus Format: Evidence from Research, Clinical Practice and Case Reports. J Diabetes Metab Disord Control. 2017;4(3):00114. Doi: 10.15406/jdmdc.2017.04.00114

92. Kamran MA Aziz. Unique glycemic and cardio-renal protective effects of metform in therapy among type-2 diabetic patients: a lesson from a five-year cross-sectional observational study of 1590 patients. Research 2014;1:874. Doi: 1:874. 10.13070/rs.en.1.874

93. Aziz KM. The Diabetic Foot Syndrome an Ignored and Potential Problem in Medical Practice. Int J Diabetol Vasc Dis Res. 2013;1(1):13. Doi: dx.doi.org/10.19070/2328-353X-130003e

94. Kamran MA Aziz. Association of Hypothyroidism with High NonHDL Cholesterol and Ankle Brachial Pressure Index in Patients with Diabetes: 10-Year Results from a 5780 Patient Cohort. A Need for Intervention. Annals Thyroid Res. 2016;2(2):53-57.

95. Kamran MA Aziz. Association between Non-HDL and HDL Cholesterol with microalbuminuria in patients with Diabetes. Journal of Diabetology. 2013;4(1):6.

96. Kamran MA Aziz. Targeting LDL Dyslipidemia for Controlling Progression of Nephropathy in Diabetic Population: A Cross Sectional Analytical Study. Journal of the Dow University of Health Sciences, Karachi 2012;6 (1): 7-11.
97. Kamran MA Aziz. Association between Hypothyroidism, Body Mass Index, Systolic Blood Pressure and Proteinuria in Diabetic Patients: Does treated Hypothyroid with Thyroxine Replacement Therapy prevent Nephropathy/ Chronic Renal Disease? Current Diabetes Reviews, 2016;12(3):297-306.

98. Sinclair SH, DelVecchio C, Levin A: Treatment of anemia in the diabetic patient with retinopathy and kidney disease. Am J Ophthalmol 2003;4(4):759-762.

99. Laville M: New strategies in anaemia management: ACORD (Anaemia CORrection in Diabetes) trial. Acta Diabetol. 2004;41(Suppl. 1):S18-S22.

100. Dahlöf B, Sever PS, Poulter NR, Wedel H, Beevers DG, et al. Prevention of cardiovascular events with an antihypertensive regimen of amlodipine adding perindopril as required versus atenolol adding bendroflumethiazide as required, in the AngloScandinavian Cardiac Outcomes Trial-Blood Pressure Lowering Arm (ASCOT-BPLA): a multicentre randomised controlled trial. Lancet 2005;366(9489):895-906.

101. Wachtell K,Palmieri V, Olsen MH, Bella JN, Aalto T, et al. Urine albumin/ creatinine ratio and echocardio graphic left ventricular structure and function in hypertensive patients with electrocardiographic left ventricular hypertrophy: the LIFE study. Losartan Intervention for Endpoint Reduction. Am Heart J. 2002;143(2):319-326.

102. Agardh CD, Garcia-Puig J, Charbonnel B, Angelkort B, Barnett AH. Greater reduction of urinary albumin excretion in hypertensive type II diabetic patients with incipient nephropathy by lisinopril than by nifedipine. J Hum Hypertens. 1996;10(3):185-192.

103. Chan JC, Ko GT, Leung DH, Cheung RC, Cheung MY, et al. Long-term effects of angiotensin-converting enzyme inhibition and metabolic control in hypertensive type 2 diabetic patients. Kidney Int 2000;57(2):590-600.

104. Laffel LM, McGill JB, Gans DJ. The beneficial effect of angiotensinconverting enzyme inhibition with captopril on diabetic nephropathy in normotensive IDDM patients with microalbuminuria. North American Microalbuminuria Study Group. Am J Med. 1995;99(5):497504.

105. Sever PS, Dahlof B, Poulter NR, Wedel H, Beevers DG, et al. Rationale, design, methods and baseline demography of participants of the Anglo-Scandinavian Cardiac Outcomes Trial. J Hypertens 2001;19(6):1139-1147.

106. Whelton PK, Carey RM, Aronow WS, Casey DE Jr, Collins KJ, Dennison Himmelfarb C, et al. Guideline for the Prevention, Detection, Evaluation, and Management of High Blood Pressure in Adults. A report of the American College of Cardiology/American Heart Association Task Force on Clinical Practice Guidelines J Am Coll Cardiol. Sep 2017, 23976; DOI: 10.1016/j.jacc.2017.07.745

107. Jellinger PS, Handelsman Y, Rosenblit PD, Bloomgarden ZT, Fonseca VA, Garber AJ et al. American Association of Clinical Endocrinologists and American College of Endocrinology Guidelines for the Management of Dyslipidemia and Prevention of Atherosclerosis. 